\begin{tabular}{c} 
Volume and Issues Obtainable at Center for Sustainability Research and Consultancy \\
Responsible Education, Learning and Teaching in Emerging Economies \\
ISSN: 2708-4310 (E): 2708-4183 \\
Volume 2: No.1, June 2020 \\
$\begin{array}{c}\text { CSRᄃ } \\
\text { Jofit }\end{array}$ \\
\hline Jlanet
\end{tabular}

\title{
Relationships between Work-Family Conflict (WFC) and Job Satisfaction of Female Faculty of Private Universities of Lahore City
}

\author{
${ }^{1}$ Sumaira Munawar, ${ }^{2}$ Khadija Sittar, \\ ${ }^{1}$ Assistant Professor, Lahore Leads University, Lahore, Pakistan, sumairamunawar16@gmail.com \\ ${ }^{2}$ Assistant Professor, Lahore Leads University, Lahore, Pakistan, khadijasittar@gmail.com
}

\begin{tabular}{l}
\hline \multicolumn{1}{c}{ ARTICLE DETAILS } \\
\hline History \\
Revised format: May 2020 \\
Available Online: June 2020 \\
Keywords \\
Work-family conflict, Job \\
satisfaction, Female faculty, Lahore \\
city
\end{tabular}

JEL Classification:

I20, I23

\section{ABSTRACT}

Present study was aimed to explore relationship between work-familyconflict and job satisfaction of female faculty of private universities of Lahore city. Study was quantitative in nature. Correlation research design was used to find out "relationship between work-family-conflict and job satisfaction of female faculty of private universities of Lahore city." Population was comprised of all the female private universities of Lahore. Sample was consisted of 450 female private university teachers of Lahore. Descriptive and inferential statistics were applied to analyse the data. Findings of the study indicated that there was significant strong positive correlation existed between work-family-conflict and job satisfaction among university teachers. A significant mean difference was found between workfamily-conflict and job satisfaction in terms of their gender, age and experience. It is recommended that work-family-conflict at workplace should be managed for teachers' job satisfaction in private universities.

\section{OPEN 2 ACCESS}

(C) 2020 The authors, under a Creative Commons AttributionNonCommercial 4.0

\footnotetext{
Corresponding author's email address: sumairamunawar16@gmail.com

Recommended citation: Munawar, S., \& Sittar, K. (2020). Relationships between Work-Family Conflict (WFC) and Job Satisfaction of Female Faculty of Private Universities of Lahore City. Responsible Education, Learning and Teaching in Emerging Economies, 2(1), 13-22
}

\section{Introduction}

Conflicts over employment and family health are a system of struggles that take place after the strength, time, or work of family conflict and behavior play a role. Family strife is a form of warfare. Family conflict is very important in society as there are important definitions of work, unemployment, and certain consequences such as "productivity", "profit", "family" "well-being", "health" and "stress". Work-related family disputes are related to important, domestic, and individual health outcomes. These include work outcomes ("job satisfaction", "commitment", and "income"), home outcomes (marital happiness and home happiness), and health-related outcomes (bodybuilding, diet and exercise) health (stress) and irreverent indications, the joy of life).

A woman, in her lifetime, goes through many roles. Many of these roles begin at home as a "daughter", "sister", "wife", "daughter-in-law" and "mother". An important problem for working women begins after the ringing of wedding rings. Roles increase when interacting with a foreign country or trying to be an active hand in better financial holding (Attri \& Neelam, 2016). 
In our society, it is a woman's primary responsibility to care for her husband's needs whether he is employed or not. Problems linking work and family life are more difficult for women because traditionally women were thought to be available during the day to care for children and do household chores (Attri \& Neelam, 2016).

Apart from the significant changes in the physical structures of Pakistan's budget, very little - or no change has taken place in Pakistan's valuing structure and cultural expectations especially as feminine. Overall, women contribute to skills development but their important roles as mothers, mothers and caregivers are different. In this system, their duties and responsibilities are doubled for lack of rest. For example, women leave their family circle to pay in the home budget without a change in the thing that links family respect and women's mobility. This situation puts a lot of pressure on women.

\subsection{Work Family Conflict}

Greenhaus and Beutell (1985) defined that it is a type of conflict that arises when the power, time, or behavior of a participant role conflicts with those within the his/her family role. The conflict in the workplace is an escalation of family and work conflict that reflects the fact that the role of work can affect people's roles and personal interests. Apart from the role of the family, this can vary from the time of friends, exercise, military service, education, recovery and rehabilitation period (Kossek, 2016), devotion, or the organization of religious organizations.

Most literature on organizational and industrial ethics uses the terms "family work" and "life work" alike to refer to personal, personal, or family life, health and professionalism, active lives (Hamilton, Gordon, and Welan-Berry, 2006). Previous traditions of domestic violence and occupation do not distinguish between references to fighting. In further controversy, no distinction is made between disputes caused by family disruption in the family, and disputes arising from family responsibilities that interfere with work. In order to keep balance in these roles the cooperative and romantic conflicts were occurred which creates conflict in the workplace and family ultimately. Robbins (2005) argued that if the personal obligations of a person would allowed to meet his work he would be satisfied at work place.

\subsection{Job Satisfaction}

Employee satisfaction is "an internal state expressed by supporting and / or assessing an employee with knowledge of a certain level of liking or dislike" (Stephen, 2017). The job satisfaction is significant because of its relations with other work outcomes, for example "productivity" and "performance cuts." According to Herrmann and Rockoff (2012) the most widely researchable area is being job satisfaction in the field of family research. Most of the studies related to the motivation the global feelings about work and working conditions was found as job satisfaction (Spector, et al., 2007). Elements of job satisfaction may include one of the aspect of work and those that have been frequently tested including payers, coworkers, supervisors, workplace and more. An international measurement method is used when interest rates are on all transactions. Previous researches has used a global measurement method, however, the methods used can determine which specific aspects of work produce human satisfaction.

\subsection{The Relation between Work-family Conflict and Job Satisfaction}

Numerous studies have found the negative relationship between WFC with job satisfaction where satisfaction was measured globally (Akinori et al., 2013). Allen et al. (2000) reported in a meta-analysis study that the WFC correlation with posted satisfaction was 0.24 and -0.23 , respectively. While meta-analyzes revealed a combination of WFC-linked weight and similar content, the results of one study could not be reversed. In another study found a negative relationship between WFC and work satisfaction (Carlson and Kacmar, 2000). Similarly, flawed relationships were observed between low-income parents in Hongkong (Lyn Craig \& Abigail Powell 2012). In a recent study there was negative correlation found between WIF and FIW with global involvement (which is an abbreviated form) of job satisfaction, and in terms of greater job satisfaction than global job satisfaction. Taken as a whole, apart from a lot of research on the relationship between family war and work and job satisfaction, there are still many statistics in the literature. For this reason, further researches are needed to simplify the understanding of the relationship that exists between different family work disputes and job satisfaction factors.

Difficulties in work and family relationships are nothing new, as many workbooks show. People have always been 
willing to take on the responsibilities of family life and work. Problems arising from work and family backgrounds were documented earlier and are respected in social science discourses (Pitt-Catsouphes, Kossek, \& Sweet, 2006). Changes in family structures and staff employment, as well as signs of social uplift have raised the bar of family and work communication. By the end of the 20th century, the number of single-parent and single-parent families had increased. As the number of women entering the profession increases, the harmony of the traditional family structure, with the husband as the primary breadwinner and the wife as the homemaker, is declining.

One of the consequences of a person's inability to manage the demands of work and family is the level of disagreement he or she faces. Greenhaus and Beutell (1985) "define family conflict as a form of conflict where the role of job stress and family backgrounds are incompatible" (p. 77). The literature review highlights three types of work and family conflicts: time-consuming conflicts, war-torn conflicts and stable conflicts. Time-bound disputes look at multiple competitive roles at the same time. Violence-based violence refers to the hardships created by a particular role, and moral conflict refers to certain patterns of moral inequality (Greenhaus \& Beutell, 1985). Netemeyer, Boles, and McMurrian (1996) incorporate these two types of work and family conflicts (time and difficulty-related difficulties) provided by Greenhaus and Beutell (1985) in their definition of the concept of family conflict. Netemeyer et al. (1996) describe family conflicts as "conflicts of interest in which the general demands of time, time allocated, and work-related difficulties affect the performance of family-related activities" (p. 401).

Pakistan is a small country but its culture reflects the origins of the oldest civilization in the world. Integrated selfesteem, asymmetrical relationships and gender considerations are fundamental values of Pakistani culture (Saher, 2010) which sets the framework for social communication and social segregation in the workplace. In traditional Pakistani society, the male is regarded as the breadwinner and female sponsor of participation (Malik \& Khalid, 2008). The rise of industry, the abolition of the agricultural system and the ongoing economic and social changes have dramatically changed the fragmentation of families and the increasing number of women, especially mothers, in the labor market. Men are no longer the breadwinner of the family as women are no longer the breadwinners of the family (Ullah, 2010).

Pressures and tasks without rest became double in this way. For example, women leave their homes to contribute to the family economy without a change in the thing that links family respect and women's mobility. This situation puts a lot of pressure on women. The Scholarship revealed that working women face many challenges in balancing their work and family responsibilities. Gordon et al. (2004) stated with limited resource, time and energy a women cannot meet the tasks and responsibilities of home and work then she reveals conflict between work and family with limited energy, resources and time. It is especially difficult for working women who are married to form a line of equality or diversity in their work and family life.

The influences that can disrupt a work ethic can be divided financially, mentally, and personally. The status and functions performed by the private sector and management are currently an emphasis on key management issues. Difficulties in staff employment and holding, mostly in the education sector, have freshly led to a re-examination of the entertainment and volunteer sector in many public and private sectors (Kendal, 2001). The problems of women, which include the different roles of wife, mother and working woman, are many; they can be categorized under a variety of topics such as physical problems, remedial problems, social problems and economic problems. The employment of women, her higher education and economic independence are sometimes seen as causes of family conflict. However, these things are often anointed with the full necessity of the economy.

\section{Statement of the Problem}

The problems of women, which include the different roles of wife, mother and working woman, are many; can be categorized under different headings such as physical problems, social problems and economic problems. The employment of women, her higher education and economic independence are sometimes seen as causes of family discord. However, these factors have often been overshadowed by the absolute economic need. People-bound culture views working women, like the first, who have missed their role in life. For them, nothing is more sacred and honorable than being a good mother and a good wife. This view is a loss. The traditional commitment of women played many roles that played a role in affecting their health. The female teacher must play multiple roles to fulfill the 
obligations, expectations, needs and needs of family members and the community. Being a teacher, women are not able to fulfill their full roles as wife, mother, teacher and social worker.

\section{Significance of the Study}

The present study might be significant for the teachers in order to solve their domestic obligations and major problems among labours. It can support teachers themselves to identify the causes of conflict and to try to resolve domestic disputes in order to achieve academic excellence and live family relationships and work disputes and job satisfaction by eliminating these causes. It can be helpful to find specific effects of work-related domestic violence (WFC) on teachers' work, home, physical and spiritual health. It can also help university administrators and administrators to manage family and work disputes to increase job satisfaction among female educators.

\section{Objectives of the Study}

Following were the research objectives of the study:

1. To explore the relationship between work family conflict and job satisfaction of private university teachers.

\section{Research Questions}

Following were the research questions of the study:

1. What is the level of work family conflict of private university teachers?

2. What is the level of job satisfaction of private university teachers?

3. Is there any significance relationship between work family conflict and job satisfaction of private university teachers?

4. Is there any significance difference among university teachers about work family conflict and job satisfaction based on their academic qualification?

5. Is there any significance difference between among university teachers about work family conflict and job satisfaction based on their professional qualification?

6. Is there any significance difference among university teachers about work family conflict and job satisfaction based on their teaching experience?

7. Is there any significance difference among university teachers about work family conflict and job satisfaction based on their age?

\section{Results}

Table 1: Level of Work Family Conflict and Job Satisfaction in terms of Academic Qualification

\begin{tabular}{llcc}
\hline Academic Qualification & & Work Family Conflict & Job Satisfaction \\
\hline \multirow{3}{*}{ M. Phil } & Mean & 94.5600 & \\
& N & 125 & 98.6800 \\
& Std. Deviation & 14.28421 & 125 \\
& & & 11.05747 \\
$\mathrm{PhD}$ & Mean & 94.8462 & \\
& N & 325 & 98.8892 \\
& Std. Deviation & 14.99694 & 325 \\
\hline
\end{tabular}

In this table findings revealed that the mean scores of female university teachers having qualification $\mathrm{PhD}$ regarding work family conflict and job satisfaction was high in terms of their qualification. It means female teachers having qualification $\mathrm{PhD}$ perceived work family conflict and job satisfaction more than the teachers having qualification MPhil at university level.

Table 2: Level of Work Family Conflict and Job Satisfaction in terms of Teaching Experience

\begin{tabular}{lccc}
\hline Teaching Experience & & $\begin{array}{c}\text { Work Family } \\
\text { Conflict }\end{array}$ & Job Satisfaction \\
& & 87.9595 & 95.1081 \\
\multirow{2}{*}{$1-5$ years } & $\mathrm{M}$ & 74 & 74 \\
\hline
\end{tabular}




\begin{tabular}{llcc}
\hline & SD & 16.25772 & 14.42559 \\
6-10 years & $\mathrm{M}$ & 90.9346 & 95.3551 \\
& $\mathrm{~N}$ & 107 & 107 \\
& $\mathrm{SD}$ & 14.33051 & 11.63214 \\
$11-15$ years & $\mathrm{M}$ & 102.0116 & 103.7907 \\
& $\mathrm{~N}$ & 86 & 86 \\
& $\mathrm{SD}$ & 13.56422 & 8.29900 \\
$16-20$ years & $\mathrm{M}$ & 100.0500 & 103.0125 \\
& $\mathrm{~N}$ & 80 & 80 \\
$21-25$ years & $\mathrm{SD}$ & 13.28452 & 8.46511 \\
& $\mathrm{M}$ & 96.2500 & 98.7188 \\
& $\mathrm{~N}$ & 64 & 64 \\
$26-30$ years & $\mathrm{SD}$ & 12.73416 & 10.40828 \\
& $\mathrm{M}$ & 88.9487 & 96.1026 \\
\hline
\end{tabular}

In this table findings revealed that the mean scores of female university teachers having experience 11-15 years regarding work family conflict and job satisfaction was high in terms of their experience. It means female teachers having experience 11-15 years perceived work family conflict and job satisfaction more than the teachers having "(15 years, 6-10 years, 16-20 years, 21-25 years and 26-30 years)" at university level.

Table 3

Level of Work Family Conflict and Job Satisfaction in terms of Age

\begin{tabular}{llcc}
\hline Age & & Work Family Conflict & Job Satisfaction \\
\hline \multirow{3}{*}{$20-25$ years } & M & 80.6316 & 84.4737 \\
& N & 19 & 19 \\
& SD & 16.95815 & 18.52436 \\
& $\mathrm{M}$ & 88.1600 & 97.1867 \\
& $\mathrm{~N}$ & 75 & 75 \\
$31-35$ years & $\mathrm{SD}$ & 15.21116 & 10.84871 \\
& $\mathrm{M}$ & 90.2857 & 95.5893 \\
& $\mathrm{~N}$ & 56 & 56 \\
$36-40$ years & $\mathrm{SD}$ & 14.03724 & 10.93414 \\
& $\mathrm{M}$ & 100.5045 & 102.2973 \\
& $\mathrm{~N}$ & 111 & 111 \\
$41-45$ years & $\mathrm{SD}$ & 13.09675 & 10.09734 \\
& $\mathrm{M}$ & 100.3793 & 101.9655 \\
& $\mathrm{~N}$ & 87 & 87 \\
$46-50$ years & $\mathrm{SD}$ & 13.99106 & 10.06889 \\
& $\mathrm{M}$ & 93.6863 & 98.0490 \\
& $\mathrm{~N}$ & 102 & 102 \\
& $\mathrm{SD}$ & 12.03623 & 9.49974 \\
\hline
\end{tabular}

In this table findings revealed that the mean scores of female university teachers having age 36-40 years regarding work family conflict and job satisfaction was high in terms of their experience. It means female teachers having age 36-40 years perceived work family conflict and job satisfaction more than the teachers having "(20-25 years, 26-30 years, 31-35 years, 41-45 years and 46-50 years)" at university level.

Table 4: Correlation between Work Family Conflict and Job Satisfaction of University Teachers

\begin{tabular}{llcrl}
\hline Variables & $M$ & $S D$ & $r$-value & Sig.
\end{tabular}




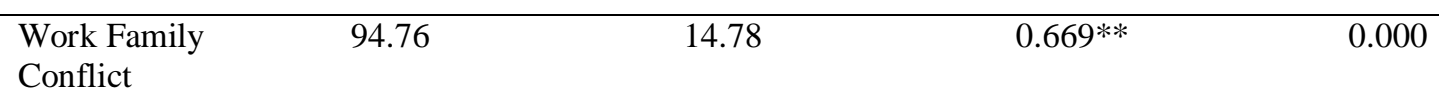

Job Satisfaction $\quad 98.83 \quad 11.31$

It was showed that "there was significant strong positive correlation between work family conflict and job satisfaction among university teachers at $\mathrm{p} \leq 0.05$ level of significance".

Table 4(a): Linear Regression about Work Family Conflict and Job Satisfaction of University Teachers

\begin{tabular}{|c|c|c|c|c|c|c|c|c|}
\hline 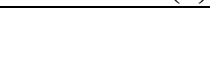 & $\begin{array}{l}\text { Un-standardized } \\
\text { Co-efficient }\end{array}$ & $\begin{array}{l}\text { Standardized Co- } \\
\text { efficient }\end{array}$ & & & & & & \\
\hline Model & $B$ & $\begin{array}{l}\text { Std. Error } \\
B\end{array}$ & $\beta$ & $T$ & $P$ & $d f$ & $F$ & $R^{2}$ \\
\hline Constant & 50.344 & 2.578 & 0.669 & 19.039 & 0.000 & 448 & 362.465 & 0.447 \\
\hline $\begin{array}{l}\text { Work Family } \\
\text { Conflict }\end{array}$ & 0.512 & 0.027 & & & & & & \\
\hline
\end{tabular}

\section{Dependent Variable Job Satisfaction}

A linear regression analysis was conducted in order to find the significance effect of work family conflict and job satisfaction of university teachers. As table 4(a) shows that "work family conflict was found to be significant with ( $\mathrm{R}^{2}$ $=0.44)$ at $\mathrm{p} \leq 0.05$ level of significance". The findings of "work family conflict and job satisfaction of university teachers significantly predict the dependent variable with $(\beta=0.66, p=0.000)$ ".

Table 5

Comparison of University Teachers' Perceptions about Work Family Conflict and Job Satisfaction regarding Academic Qualification

\begin{tabular}{llllllll}
\hline Variables & $\begin{array}{l}\text { Academic } \\
\text { Qualification }\end{array}$ & $N$ & $M$ & $S D$ & Df & t- value & Sig. \\
\hline Work Family & M. Phil & 125 & 94.56 & 14.28 & 448 & -0.184 & 0.057 \\
Conflict & PhD & 325 & 94.84 & 14.99 & & & \\
& & & & & & & \\
Job Satisfaction & M. Phil & 125 & 98.68 & 11.05 & 448 & -0.176 & 0.513 \\
& PhD & 325 & 98.88 & 11.42 & & & \\
\hline
\end{tabular}

An independent samples t-test was applied to find out the differences of university teachers' perceptions about work family conflict and job satisfaction regarding academic qualification. It is indicated that "no significant mean difference found between university teachers' perceptions about work family conflict and job satisfaction at $\mathrm{p} \leq 0.05$ level of significance".

Table 4.6: Comparison of University Teachers' Perceptions about Work Family Conflict and Job Satisfaction regarding Experience

\begin{tabular}{llllll}
\hline Variables & $S S$ & $M S$ & $D f$ & $F$ & Sig. \\
& & & & & \\
\hline Work Family & 13208.394 & 2641.679 & 5 & 13.804 & \\
Conflict & 84970.106 & 191.374 & 444 & & \\
& 98178.500 & & 449 & & \\
& & & & & \\
Job Satisfaction & 6123.777 & 1224.755 & 5 & 10.591 & \\
& 51345.387 & 115.643 & 444 & & \\
& 57469.164 & & 449 & & \\
\hline
\end{tabular}

A one-way ANOVA was applied to find out the differences of university teachers' perceptions about work family conflict and job satisfaction regarding their experience. It is indicated that "a significant mean difference was found 
between university teachers' perceptions about work family conflict and job satisfaction at $\mathrm{p} \leq 0.05$ level of significance".

Table 6 (a): Post- hoc test of difference of University Teachers' Perceptions about Work Family Conflict and Job Satisfaction regarding Experience

\begin{tabular}{|c|c|c|c|c|}
\hline Experience & Experience $(a)$ & Experience $(b)$ & Mean Difference & $P$ \\
\hline Work Family & $1-5$ Years & $11-15$ Years & $-14.05217^{*}$ & 0.000 \\
\hline \multirow[t]{13}{*}{ Conflict } & & $16-20$ years & $-12.09054^{*}$ & 0.000 \\
\hline & & $21-25$ years & $-8.29054^{*}$ & 0.007 \\
\hline & $6-10$ Years & $11-15$ years & $-11.07705^{*}$ & 0.000 \\
\hline & & $16-20$ years & $-9.11542^{*}$ & 0.000 \\
\hline & $11-15$ Years & $1-5$ years & $14.05217^{*}$ & 0.000 \\
\hline & & $6-10$ years & $11.07705^{*}$ & 0.000 \\
\hline & & $26-30$ years & $13.06291^{*}$ & 0.000 \\
\hline & $16-20$ Years & $1-5$ years & $12.09054^{*}$ & 0.000 \\
\hline & & $6-10$ years & $9.11542^{*}$ & 0.000 \\
\hline & & $26-30$ years & $11.10128 *$ & 0.000 \\
\hline & 21-25 Years & $1-5$ years & $8.29054^{*}$ & 0.007 \\
\hline & 26-30 Years & $11-15$ years & $-13.06291^{*}$ & 0.000 \\
\hline & & $16-20$ years & $-11.10128 *$ & 0.001 \\
\hline \multirow[t]{12}{*}{ Job Satisfaction } & $1-5$ Years & $11-15$ years & $-8.68259 *$ & 0.000 \\
\hline & & $16-20$ years & $-7.90439 *$ & 0.000 \\
\hline & $6-10$ Years & $11-15$ years & $-8.43556^{*}$ & 0.000 \\
\hline & & $16-20$ years & $-7.65736^{*}$ & 0.000 \\
\hline & $11-15$ Years & $1-5$ years & $8.68259^{*}$ & 0.000 \\
\hline & & $6-10$ years & $8.43556^{*}$ & 0.000 \\
\hline & & 26-30 Years & $7.68813^{*}$ & 0.003 \\
\hline & $16-20$ Years & 1-5 Years & $7.90439 *$ & 0.000 \\
\hline & & $6-10$ Years & $7.65736^{*}$ & 0.000 \\
\hline & & 26-30 Years & $6.90994^{*}$ & 0.014 \\
\hline & 26-30 Years & $11-15$ Years & $-7.68813^{*}$ & 0.003 \\
\hline & & $16-20$ Years & $-6.90994^{*}$ & 0.014 \\
\hline
\end{tabular}

A post hoc (Tukey) was applied to find out the differences of university teachers' perceptions about work family conflict and job satisfaction regarding their experience. It is indicated that a significant difference was found between teachers' perceptions in terms of their experience regarding work family conflict and job satisfaction.

Table 7: Comparison of University Teachers' Perceptions about Work Family Conflict and Job Satisfaction regarding their Age

\begin{tabular}{llllll}
\hline Variables & $S S$ & $M S$ & $D f$ & $F$ & Sig. \\
& & & & & \\
\hline Work Family & 14708.379 & 2941.676 & 5 & 15.648 & \\
Conflict & 83470.121 & 187.996 & 444 & & \\
& 98178.500 & & 449 & & \\
& & & & & \\
Job Satisfaction & 6958.647 & 1391.729 & 5 & & \\
& 50510.518 & 113.762 & 444 & & \\
& 57469.164 & & 449 & & \\
\hline
\end{tabular}

A one-way ANOVA was applied to find out the differences of university teachers' perceptions about work family conflict and job satisfaction regarding their age. It is indicated that "a significant mean difference was found between university teachers' perceptions about work family conflict and job satisfaction at $\mathrm{p} \leq 0.05$ level of significance". 
Table 7 (a): Post- hoc test of difference of University Teachers' Perceptions about Work Family Conflict and Job Satisfaction regarding Age

\begin{tabular}{|c|c|c|c|c|}
\hline Age & Age (a) & Age (b) & Mean Difference & $P$ \\
\hline Work Family & $20-25$ Years & $36-40$ Years & $-19.87293^{*}$ & 0.000 \\
\hline \multirow[t]{13}{*}{ Conflict } & & 41-45 Years & $-19.74773^{*}$ & 0.000 \\
\hline & & 46-50 Years & $-13.05470^{\circ}$ & 0.002 \\
\hline & 26-30 Years & 36-40 Years & $-12.34450^{*}$ & 0.000 \\
\hline & & 41-45 Years & $-12.21931^{*}$ & 0.000 \\
\hline & 31-35 Years & 36-40 Years & $-10.21879 *$ & 0.000 \\
\hline & & 41-45 Years & $-10.09360^{\circ}$ & 0.000 \\
\hline & 36-40 Years & 20-25 Years & $19.87293^{*}$ & 0.000 \\
\hline & & 26-30 Years & $12.34450^{*}$ & 0.000 \\
\hline & & 31-35 Years & $10.21879 *$ & 0.000 \\
\hline & & 46-50 Years & $6.81823^{*}$ & 0.004 \\
\hline & 41-45 Years & 20-25 Years & $19.74773^{*}$ & 0.000 \\
\hline & & 26-30 Years & $12.21931^{*}$ & 0.000 \\
\hline & & 31-35 Years & $10.09360^{*}$ & 0.000 \\
\hline \multirow{22}{*}{ Job Satisfaction } & & 46-50 Years & $6.69304^{*}$ & 0.011 \\
\hline & 46-50 Years & 20-25 Years & $13.05470^{*}$ & 0.002 \\
\hline & & 36-40 Years & $-6.81823^{*}$ & 0.004 \\
\hline & & 41-45 Years & $-6.69304^{*}$ & 0.011 \\
\hline & 20-25 Years & 26-30 Years & $-12.71298^{*}$ & 0.000 \\
\hline & & 31-35 Years & $-11.11560^{*}$ & 0.001 \\
\hline & & $36-40$ Years & $-17.82361^{*}$ & 0.000 \\
\hline & & 41-45 Years & $-17.49183^{\circ}$ & 0.000 \\
\hline & & 46-50 Years & $-13.57534^{*}$ & 0.000 \\
\hline & 26-30 Years & $20-25$ Years & $12.71298^{\circ}$ & 0.000 \\
\hline & & 36-40 Years & $-5.11063^{\circ}$ & 0.018 \\
\hline & 31-35 Years & 20-25 Years & $11.11560^{\circ}$ & 0.001 \\
\hline & & 36-40 Years & $6.70801 \%$ & 0.002 \\
\hline & & 41-45 Years & $6.37623^{*}$ & 0.044 \\
\hline & $36-40$ Years & 20-25 Years & $17.49183^{*}$ & 0.000 \\
\hline & & 26-30 Years & $5.11063^{*}$ & 0.007 \\
\hline & & 31-35 Years & $6.70801^{*}$ & 0.000 \\
\hline & & $46-50$ Years & $4.24828^{\circ}$ & 0.044 \\
\hline & 41-45 Years & 20-25 Years & $17.49183^{\circ}$ & 0.000 \\
\hline & & 31-35 Years & $6.37623^{\circ}$ & 0.007 \\
\hline & 46-50 Years & $20-25$ Years & $13.57534^{*}$ & 0.000 \\
\hline & & $36-40$ Years & $-4.24828^{\circ}$ & 0.044 \\
\hline
\end{tabular}

A post hoc (Tukey) was applied to find out the differences of university teachers' perceptions about work family conflict and job satisfaction regarding their experience. It is indicated that a significant difference was found between teachers' perceptions in terms of their age regarding work family conflict and job satisfaction.

\section{Discussion}

In the present world of business the most considerable issue is work-family conflict. The interest in the conflict between domains of work and life is increased in recent years. In addition to this, the difference of role played by individuals at work and home is headed as work-family conflict as highlighted by previous studies. Finding out relationship between conflict at work-family and job satisfaction of university teachers was the objective of the study. "A strong relationship between work-family conflict and job satisfaction of university teachers was revealed by the findings of the study as positive significant". These findings concluded that conflict between work and family has significantly affected teachers' job satisfaction at university level. The study conducted by Carly, Allen, and Spector, The University of South Florida (2002) supported the findings of this study which concluded that work-family conflict (WFC) are interrelated (WFC) and by using a six-dimensional measure of WFC and both global as well as summed facet (i.e., composite) measures of job satisfaction, the job satisfaction was examined . The resultant indications showed significant relationship of WFC job satisfaction of both types, however, the relationship was considerably stronger to composite job satisfaction than to global job satisfaction. Another study Rehman, et al. (2018) concluded that there was moderate positive correlation found between two variables with moderating effect of 
gender on WFC and job satisfaction of university teachers.

In regards of academic qualification, there was no major mean differentiation observed between perceptions of university teachers with reference to conflict of work-family and job satisfaction at $\mathrm{p} \leq 0.05$ level of significance. Moreover, a significant mean difference originated between perceptions of university teachers concerning workfamily conflict and job satisfaction on the subject of teachers' experience and age was exposed at university level.

\section{Recommendations}

Following were the recommendations of the study.

1. In order to increase teachers' job satisfaction famly members and administration play a potential role to facilitate them and training sessions are need to conduct for reducing conflicts at workplace.

2. A study on work family conflict and job satisfaction might be conducted at elementary, secondary and college level.

3. It is recommended that study on work family conflict and job satisfaction might be conducted at large sample.

4. A qualitative study might be conducted on teachers' work family conflict and job satisfaction for in depth investigation.

\section{References}

Allen, T. D., Herst, D. E., Bruck, C. S., \& Sutton, M. (2000). Consequences associated with work-to-family conflict: a review and agenda for future research. Journal of Occupational Health Psychology, 5(2), 278-287.

Afzal, S., \& Farooqi, Y. A. (2014). Impact of work family conflict/family work conflict on job satisfaction and life satisfaction: A case study of a public sector university, Gujranwala Division, Pakistan. International Journal of Multidisciplinary Science and Engineering, 5(8), 31-36.

Attri, A. K., \& Neelam, G. (2016). work-family conflict among female teachers in relation to type of school, their nature of job and job satisfaction. International Journal of Educational Research, 2(10), 792-800.

Eby, L. T., Casper, W. J., Lockwood, A., Bordeaux, C., \& Brinley, A. (2005). Work and family research in IO/OB: Content analysis and review of the literature (1980-2002). Journal of Vocational Behavior, 66(1), 124-197.

Greenhaus, J. H., \& Beutell, N. J. (1985). Sources of conflict between work and family roles. Academy of Management Review, 10, 76-88.

Hamilton, E. A., Gordon, J. R., \& Whelan-Berry, K. S. (2006). Understanding the work-life conflict of never-married women without children. Women in Management Review.

Grandey, A., L Cordeiro, B., \& C Crouter, A. (2005). A longitudinal and multi-source test of the work-family conflict and job satisfaction relationship. Journal of occupational and Organizational Psychology, 78(3), 305-323.

Gordon, J. R., Karen, S., \& Berry, W. (2004). It takes two to tango:

An empirical study of perceived spousal/partner support for working women', Women in Management Review, 19(5), 260-273. DOI: 10.1108/09649420410545980.

Herrmann, M. A., \& Rockoff, J. E. (2012). Worker absence and productivity: Evidence from teaching. Journal of Labor Economics, 30(4), 749-782.

Kim, J. L. S., \& Ling, C. S. (2001). Work-family conflict of women entrepreneurs in Singapore. Women in Management review.

Kossek, E. E., \& Lee, K. H. (2017). Work-family conflict and work-life conflict. In Oxford Research Encyclopedia of Business and Management.

Lapierre, L. M., Spector, P. E., Allen, T. D., Poelmans, S., Cooper, C. L., O’Driscoll, M. P., ... \& Kinnunen, U. (2008). Family-supportive organization perceptions, multiple dimensions of work-family conflict, and employee satisfaction: A test of model across five samples. Journal of Vocational Behavior, 73(1), 92-106.

Luk, D. M., \& Shaffer, M. A. (2005). Work and family domain stressors and support: Within-and cross-domain influences on work-family conflict. Journal of Occupational and Organizational Psychology, 78(4), 489508.

Malik, A., \& Khalid, G. K. (2008). Work/life conflicts and desired work hour adjustments: Banking perspective in Pakistan. International Review of Business Research Papers, 4(5), 267-276. 
Netemeyer, R. G., Brashear-Alejandro, T., \& Boles, J. S. (2004). A cross-national model of jobrelated outcomes of work-role and family role variables: A retail sales context. Journal of the Academy of Marketing Science, $32,49-60$.

Noor, N. M. (2004). Work-family conflict, work -and family role saliente, and women's well-being. J. Soc. Psychol, $144,389-405$.

Pitt-Catsouphes, M., Kossek, E. E., \& Sweet, S. (Eds.). (2015). The work and family handbook: Multi-disciplinary perspectives and approaches. Routledge.

Robbins, S. P. (2005). Administración. Pearson educación. New York: Sage Publishers.

Spector, P. E., Allen, T. D., Poelmans, S. A. Y., Lapierre, M. L., Cooper, C. L., \& Widerszal-Bazyl, M. (2007). Cross-national differences in relationships of work demands, job satisfaction, and turnover intentions with work-family conflict. Personnel Psychology, 60, 805-835.

Saher, N. (2010). Cultural diversity and human resource development in a modern organization: A case study (Unpublished PhD dissertation). Quaid-e-Azam University, Islamabad, Pakistan.

Ullah, S. (2010, January). Perceived workplace support and work-family conflict: A case study of married admin staff members of Punjab University, Lahore. In Conference Paper presented at 10th National Research Conference, Shaheed Zulfiqar Ali Bhutto Institute of Information Technology (SZABIST), January. 